\title{
Neuralgic amyotrophy
}

INSERM

\section{Source}

INSERM. (1999). Orphanet: an online rare disease and orphan drug data base. Neuralgic amyotrophy. ORPHA:2901

Neuralgic amyotrophy (NA) is an uncommon disorder of the peripheral nervous system characterized by the sudden onset of extreme pain in the upper extremity followed by rapid multifocal motor weakness and atrophy and a slow recovery in months to years. NA includes both an idiopathic (INA, also known as Parsonage-T urner syndrome) and hereditary (HNA) form. 